\title{
A reference guide to Smith predictor based methods for the compensation of dead-time processes
}

Aidan O'Dwyer

Technological University Dublin, aidan.odwyer@tudublin.ie

Follow this and additional works at: https://arrow.tudublin.ie/engscheleart

Part of the Controls and Control Theory Commons

\section{Recommended Citation}

O'Dwyer, Aidan : A reference guide to Smith predictor based methods for the compensation of dead-time processes. Proceedings of the IEE Irish Signals and Systems Conference, pp. 231-238, Dublin City University, September, 2005. doi:10.21427/6sck-s480

This Conference Paper is brought to you for free and open access by the School of Electrical and Electronic Engineering at ARROW@TU Dublin. It has been accepted for inclusion in Conference papers by an authorized administrator of ARROW@TU Dublin. For more information, please contact arrow.admin@tudublin.ie, aisling.coyne@tudublin.ie,gerard.connolly@tudublin.ie. 


\title{
A reference guide to Smith predictor based methods for the compensation of dead-time processes
}

\author{
Aidan O'Dwyer \\ School of Control Systems and Electrical Engineering, \\ Dublin Institute of Technology, \\ Kevin St., Dublin 8, Ireland \\ E-mail: aidan.odwyer@dit.ie
}

\begin{abstract}
An extensive literature exists on the compensation of time delayed processes. These compensation methods may be broadly divided into parameter optimised controllers, in which the controller parameters are adapted to the controller structure (the most common such controller is the proportional integral derivative, or PID, controller), and structurally optimised controllers, in which the controller structure and parameters are adapted optimally to the structure and parameters of the process model. Important structurally optimised compensator strategies are the Smith predictor and its variations. The purpose of this paper is to extract the essence of the developments in design, tuning and implementation of these controllers. In addition, an original variation on the Smith predictor structure is detailed.

Keywords - Time delay, compensation, Smith predictor.
\end{abstract}

\section{INTRODUCTION}

A time delay may be defined as the time interval between the start of an event at one point in a system and its resulting action at another point in the system. Delays are also known as transport lags or dead times; they arise in physical, chemical, biological and economic systems, and in measurement and computation. In manufacturing applications, delays typically arise whenever there is physical transport of material, for example, in a pipe or on a conveyer belt; the delay can be determined as the ratio of distance to be traveled to the speed of the material. Delays arise in a wide variety of other manufacturing applications, often in combination with other process dynamics; examples of such applications range from plastic part fabrication to heating, ventilation and air conditioning (HVAC) to industrial sewing machines.

The PID controller has traditionally been used to control processes with and without time delay, with some success; a large number of tuning rules (formulae) exist to set up the controller parameters [1]. In process control applications, more than $90 \%$ $95 \%$ of the controllers are of PID type [2-7]. However, PID controllers are less effective if the time delay term in the process dynamics is dominant. For such applications, the Smith predictor can give better performance. Though well known to the academic control engineering community, a recent survey of industrial practice in Scotland [6] has revealed only a single use of the Smith predictor. Hence, the motivation of this paper is to bring the extensive academic work on the Smith predictor to the attention of the wider systems community.

\section{THE SMITH PREDICTOR}

The design of controllers for processes with long time delays has been of interest to academics and practitioners for several decades. In a seminal contribution, Smith [8] proposed a technique that reduces the dominance of the delay term in the closed loop characteristic equation; a 'primary' controller may then be designed for the nondominant delay process. This method, called the Smith predictor, has been the subject of numerous experimental and theoretical studies. A block diagram of the Smith predictor is provided in Figure 1 .

The applicability of the Smith predictor, especially compared to the PID controller, has been examined [9-23]; Seborg et al. [9], for instance, quote studies stating that the Smith predictor performance for servo applications is up to $30 \%$ better than the use of an appropriately tuned PID controller.

The Smith predictor is the optimal controller for a delayed process for servo applications, or for a step disturbance, if the optimal controller is designed using a constrained minimum output variance control law. If the disturbance is not of step form, then the optimal controller may be specified for regulator applications by the inclusion of an appropriate dynamic element in the feedback path of the Smith predictor structure [24-36]. The Smith 
Figure 1: Block diagram of the Smith predictor structure

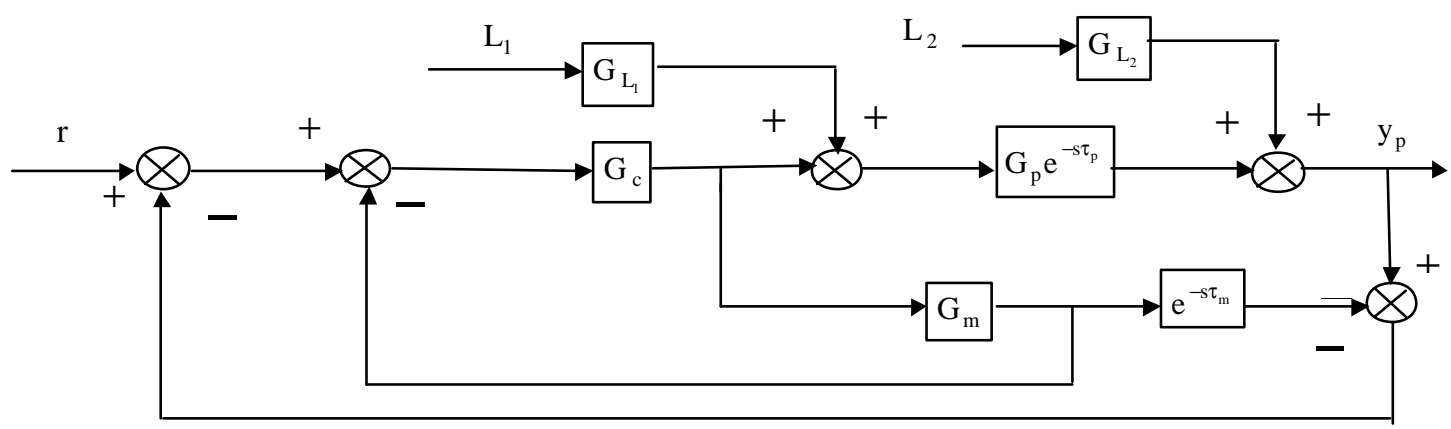

The Smith predictor has been investigated in many simulation and implementation studies [4656]; Singh and McEwan [47], for instance, consider the implementation of the predictor, realised in continuous time, in a laboratory case study. Modifications of the Smith predictor, such as the predictive PI controller proposed by Hagglund [57], have also been discussed [2, 58-72]. Other contributions are also of interest [73-78].

In real applications, it is inevitable that the model will not be a perfect representation of the process, perhaps because the process and model are of different structure or because the process parameters change in an unknown way with operating conditions. The presence of such mismatch means that perfect delay compensation using the Smith predictor is not possible. In these circumstances, the model parameters in the Smith predictor could be adaptively updated as the process parameters vary [17, 53, 79-90]. The difficulty with many adaptive approaches is that the closed loop system may be unstable as a result of the mismatch, before the model parameters are updated to the process parameters. The conditions for stability in the presence of mismatch may be calculated using numerical techniques in both the time and frequency domains, though knowledge of the process parameters is required. An alternative is to specify robust stability and performance require ments for the Smith predictor implementation in the presence of mismatch [17, 34, 38, 91-107]; the internal model control (IMC) strategy is sometimes used in the analysis. Laughlin et al. [93], for instance, define a single multiplicative perturbation to represent the uncertainty in several process parameters; the authors subsequently derive analytical conditions for robust stability and robust performance of the Smith predictor, with the IMC procedure being used to formulate the primary controller. Other pplications of the IMC strategy have also been recorded [9, 108110]. Interestingly, some authors consider creating a deliberate mismatch between the process and model parameters to improve stability or performance [111118].
The Smith predictor is designed with servo applications in mind. Modifications of the Smith predictor have been discussed to improve the regulator properties of the compensated system and/or the performance of the compensated system in the presence of measurement noise and process parameter variations $[17,25,31,32,64,80,95,114$, 119-151]. Some authors, for example, suggest that improved responses may be obtained if appropriate dynamic terms are included in either the outer feedback loop or the inner feedback loop (e.g. [25, $31,80,114,123,126,131,139])$.

Smith predictors are often implemented in discrete time, as it is more straightforward to implement a delay in this domain than in the continuous time domain (at least if the delay is an integer multiple of the sample period). Analytical procedures to investigate the robustness of the predictor, operating under process-model mismatch conditions in discrete time, have been developed $[152,153]$. It is common to estimate the model parameters before designing the primary controller; the delay may be estimated explicitly or the model may be overparameterised, without an explicit estimation of the delay [154-161]. Modifications of the Smith predictor have also been considered [42, 162-179]. A closely related structure is the analytical predictor $[9,59,125,180-183]$ and generalised analytical predictor $[9,125,184-186]$, which includes a disturbance filter in the feedback path; these algorithms combine good regulation behaviour with delay compensation. The IMC methodology may also be implemented in the discrete time domain [9, 108, 187-191]. More recently, generalised predictive controllers have been defined using the Smith predictor structure [192-194].

Generalised continuous time and discrete time Smith predictors have been proposed to control delayed MIMO processes [26, 30, 123, 195-210]. The robustness of these predictors is also discussed [211-214]; Feng [214], for example, derives a sufficient condition for compensator stability. Compensation of delayed MIMO processes, using the IMC approach, is also described [92, 215-220].

It is not possible to compensate unstable delayed processes with a Smith predictor, as the 
poles of the compensated closed loop system always contain those of the unstable process [221]. A modified Smith predictor for the control of an unstable delayed process with one unstable pole has been detailed [222]. Other such compensation strategies for unstable SISO delayed processes are also proposed [120, 150, 223-225].

\section{MODIFIED SMITH PREDICTOR DESIGN}

A new modified Smith predictor which facilitates a servo response similar to that of the Smith predictor, with a modestly improved regulator response, is detailed. The block diagram of the modified Smith predictor is shown in Figure 2, assuming a disturbance input on $\mathrm{L}_{1}$ only. The dynamic term in the outer feedback loop is an approximation for the unrealizable time advance term, $\mathrm{e}^{\mathrm{s} \tau_{\mathrm{m}}}$, which would significantly improve the regulator response. The term $\mathrm{B}(\mathrm{s})=(\mathrm{as}+1) /(\mathrm{as}+\mathrm{p}), \mathrm{p}>1$; $\mathrm{a}$ is chosen as the time constant of a FOLPD plant model, with $p$ chosen iteratively.

A number of simulation results, carried out in SIMULINK, showing the operation of the method are provided below. Nominal $\mathrm{G}_{\mathrm{p}} \mathrm{e}^{-\mathrm{s} \tau_{\mathrm{p}}}=2 \mathrm{e}^{-\mathrm{s}} / 1+8.5 \mathrm{~s}+22.5 \mathrm{~s}^{2}+18 \mathrm{~s}^{3} . \quad \mathrm{G}_{\mathrm{m}} \mathrm{e}^{-\mathrm{s} \tau_{\mathrm{m}}} \quad$ is specified using the identification method described by O'Dwyer and Ringwood [226] i.e. $\mathrm{G}_{\mathrm{m}} \mathrm{e}^{-\mathrm{s} \tau_{\mathrm{m}}}=1.82 \mathrm{e}^{-3.47 \mathrm{~s}} /(1+7.68 \mathrm{~s})$. The process parameter values are allowed to vary between upper and lower limits; a $\pm 30 \%$ variation in process time delay is allowed, with a similar variation in the other non-gain process parameters; a $\pm 40 \%$ variation in the gain is permitted. Following the procedure outlined, $\quad \mathrm{B}(\mathrm{s})=(7.68 \mathrm{~s}+1) /(7.68 \mathrm{~s}+20) . \quad \mathrm{G}_{\mathrm{c}} \quad$ is specified assuming a servo time constant of $2.0 \mathrm{~s}$, when the process and model parameters coincide i.e. $\mathrm{G}_{\mathrm{c}}=2.11(1+1 / 7.68 \mathrm{~s})$.

Figure 2: Block diagram of the modified Smith predictor structure

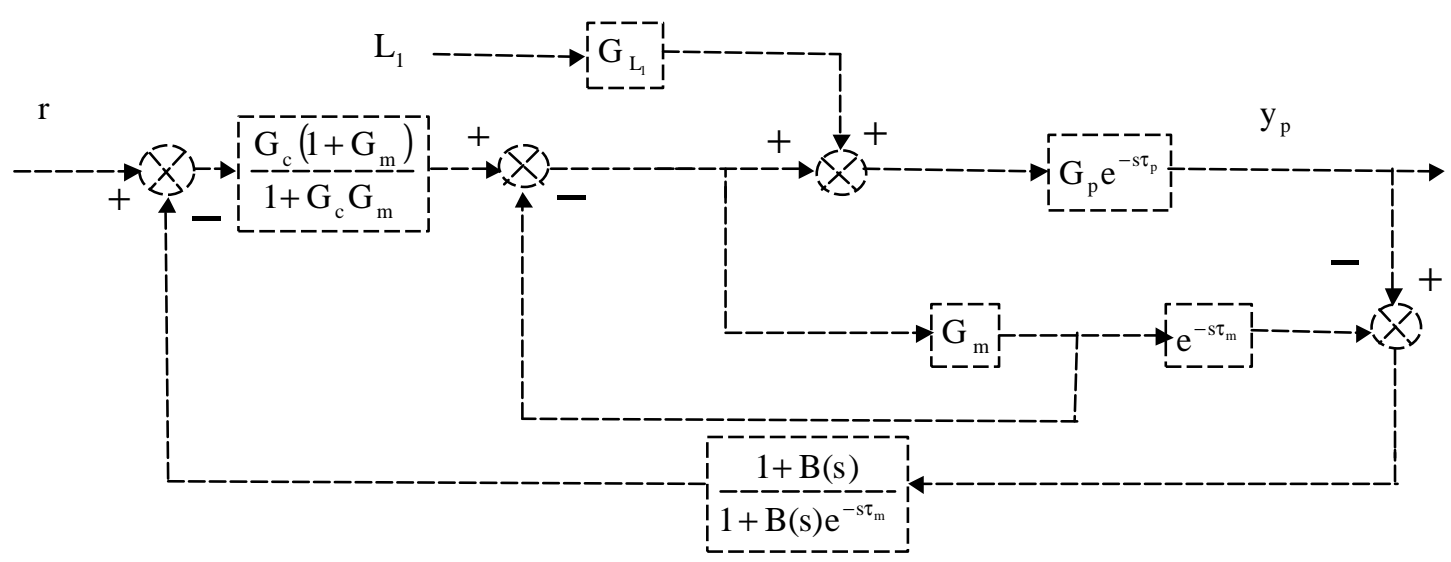

Regulator response

Servo response

(a) $\mathrm{G}_{\mathrm{p}} \mathrm{e}^{-\mathrm{s} \tau_{\mathrm{p}}}=1.2 \mathrm{e}^{-0.7 \mathrm{~s}} / 1+5.9 \mathrm{~s}+15.7 \mathrm{~s}^{2}+12.6 \mathrm{~s}^{3}, \mathrm{G}_{\mathrm{m}} \mathrm{e}^{-\mathrm{s} \tau_{\mathrm{m}}}=1.82 \mathrm{e}^{-3.47 \mathrm{~s}} /(1+7.68 \mathrm{~s})$
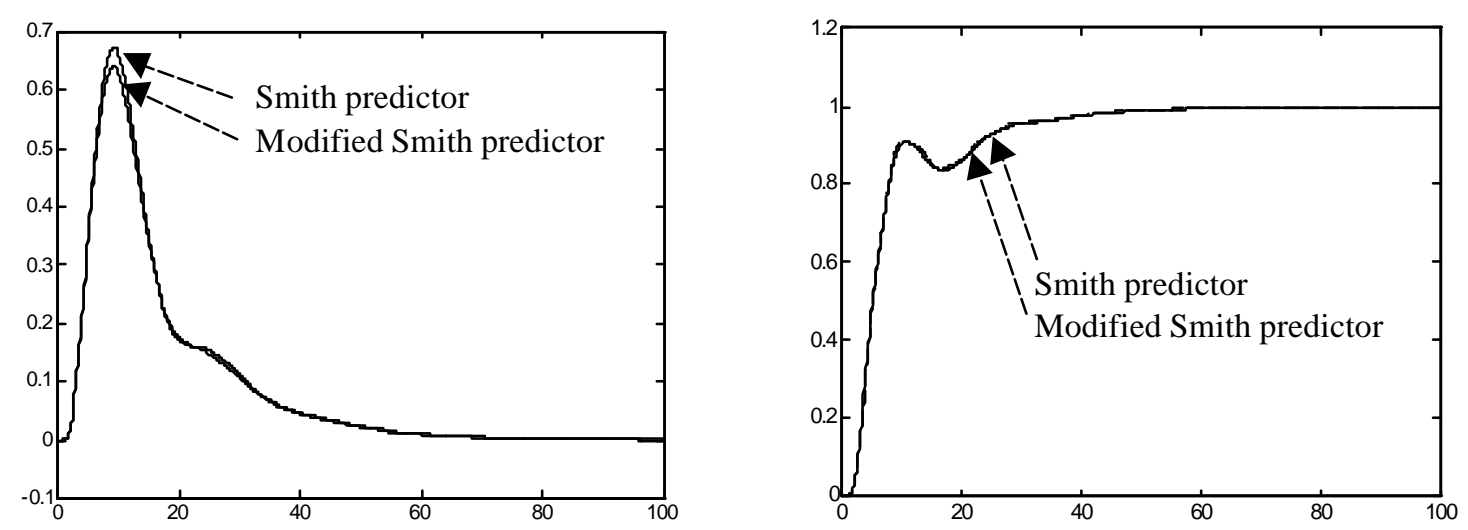
(b) $\mathrm{G}_{\mathrm{p}} \mathrm{e}^{-\mathrm{s} \tau_{\mathrm{p}}}=2 \mathrm{e}^{-\mathrm{s}} / 1+8.5 \mathrm{~s}+22.5 \mathrm{~s}^{2}+18 \mathrm{~s}^{3}, \mathrm{G}_{\mathrm{m}} \mathrm{e}^{-\mathrm{s} \tau_{\mathrm{m}}}=1.82 \mathrm{e}^{-3.47 \mathrm{~s}} /(1+7.68 \mathrm{~s})$
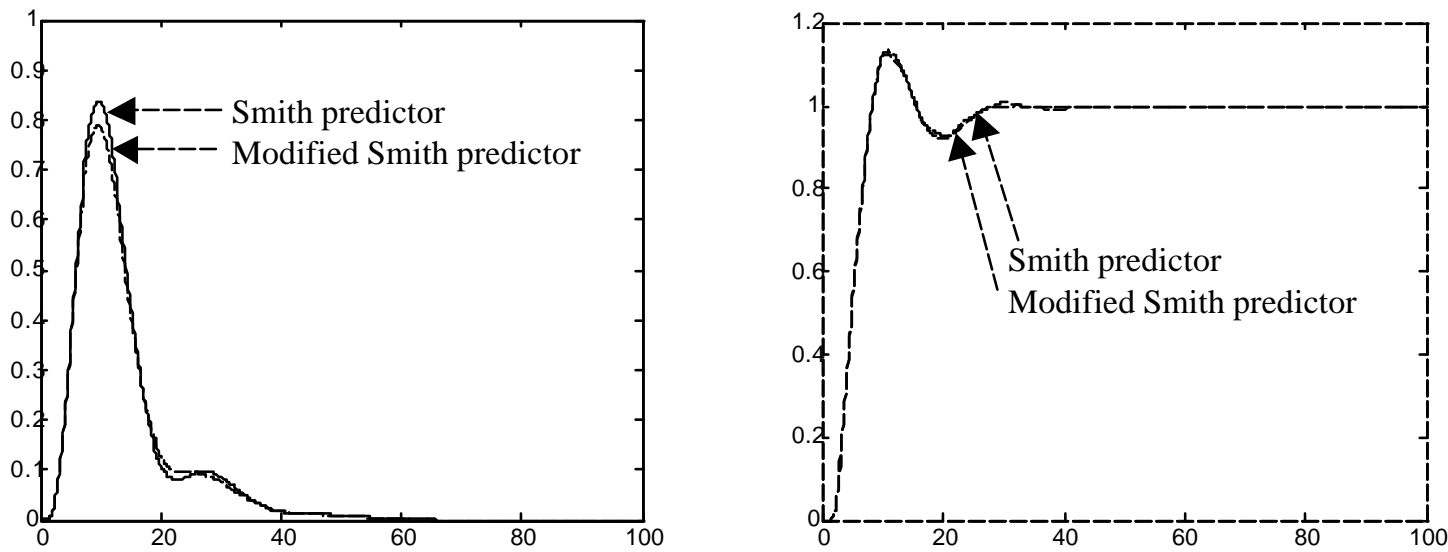

(c) $\mathrm{G}_{\mathrm{p}} \mathrm{e}^{-\mathrm{s} \tau_{\mathrm{p}}}=2.8 \mathrm{e}^{-1.3 \mathrm{~s}} / 1+11 \mathrm{~s}+29.3 \mathrm{~s}^{2}+23.4 \mathrm{~s}^{3}, \mathrm{G}_{\mathrm{m}} \mathrm{e}^{-s \tau_{\mathrm{m}}}=1.82 \mathrm{e}^{-3.47 \mathrm{~s}} /(1+7.68 \mathrm{~s})$

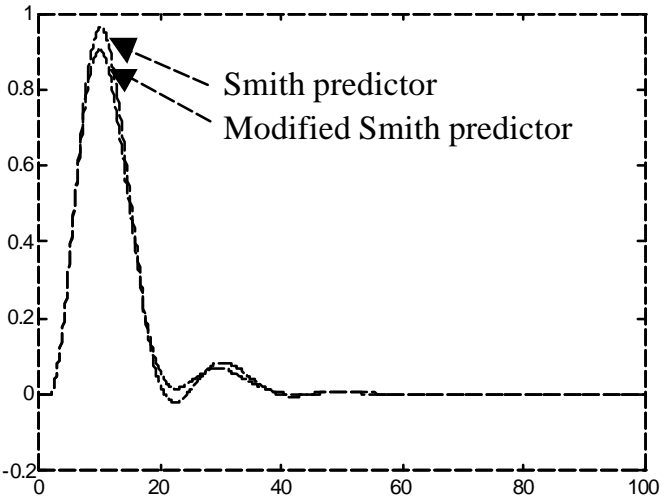

The results show that the modified Smith predictor facilitates a modest improvement in regulator responses, with similar servo responses, compared to the Smith predictor, if the desired servo response is relatively slow.

\section{CONCLUSIONS}

Dead time compensators are appropriate for the control of dominant delay processes. The survey reveals the high level of interest in the use of the Smith predictor and its variations, at least in the academic research community. In general, there is a lack of comparative analysis regarding the performance and robustness of closed loop systems compensated by these dead time controllers. Comparative analysis of these compensators with PID compensators is also sparse, though it has been stated that dead time compensators of the type discussed facilitate, in general, less robust results than PID controllers, and are particularly sensitive to variations in process gain and delay, which are the process parameters most likely to change [59]. In addition, there are few tuning rules defined to allow straightforward determination of the compensator parameters (in contrast to the large number of tuning rules available for the determination of PID controller parameters). Future work should concentrate on the development of dead time compensator tuning rules and a critical analysis of existing dead-time compensator strategies.

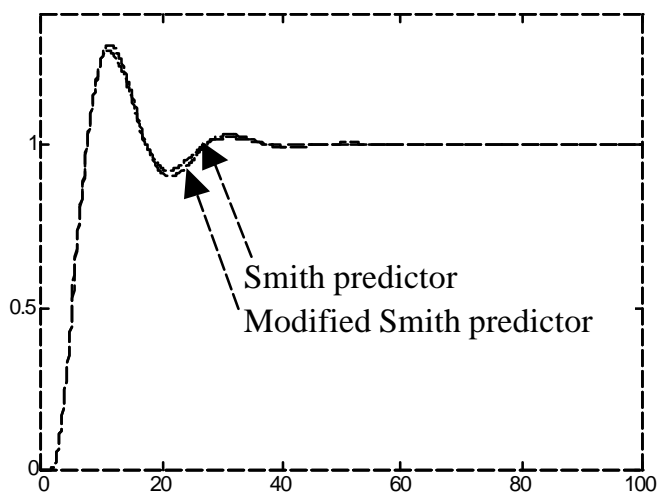

\section{REFERENCES}

[1] O'Dwyer, A. Handbook of PI and PID controller tuning rules. London, U.K.: Imperial College Press, 2003.

[2] Astrom, K.J. and Hagglund, T. (1995). PID controllers: theory, design and tuning, Second Edition, Instrument Society of America.

[3] Koivo, H.N. and Tanttu, J.T. (1991). Proc. IFAC Intelligent Tuning Adaptive Control Symp., Singapore, 75.

[4] Bialkowski, W.L. (1996), in The Control Handbook, W.S. Levine, Ed. Boca Raton, Florida: CRC/IEEE Press, 1219.

[5] Luyben, W.L. and Luyben, M.L. (1997) Essentials of process control. Singapore: McGraw-Hill International Edition.

[6] Hersh, M.A, and M.A. Johnson, M.A. (1997), Control Eng. Practice, 5(6), 771.

[7] Takatsu, T. and Itoh, T. (1999), IEEE Trans. Control Syst. Tech., 7(3), 298.

[8] Smith, O.J.M. (1957). Chemical Engineering Progress, 53, 217.

[9] Seborg, D.E., Edgar, T.F. and Mellichamp, D.A. (1989). Process dynamics and control, John Wiley and Sons.

[10] Meyer, C., Seborg, D.E. and Wood, R.K. (1976). Chemical Engineering Science, 31, 775.

[11] Meyer, C., Seborg, D.E. and Wood, R.K. (1978). Industrial and Engineering Chemistry Process Design and Development, 17(1), 62.

[12] Hang, C.C., Tan, C.H. and Chan, W.P. (1980). IEEE Transactions on Industrial Electronics and Control Instrumentation, 27(3), 234.

[13] Horowitz, I. (1983). International Journal of Control,38, 977. 
[14] Mee, D.K., Asbury, W.L., Kaiser, K.W. and Orejuela, M. (1986). Proc. ISA/86 International Conference, Houston, U.S.A., 41(2), 765.

[15] Hill, A.G. and Kanpittaya, S. (1989). Proc. ISA/89 International Conference and Exhibition, Philadelphia, Pa., U.S.A., 44(1), 35.

[16] Waggoner, R.C. and Witt, S.D. (1989). Proc. ISA/89 International Conference and Exhibition, Philadelphia, Pa., U.S.A., 44(1), 79.

[17] Palmor, Z.J. and Blau, M. (1994). International Journal of Control, 60, 117

[18] McMillan, G.K. (1994). Tuning and control loop performance - a practitioner's guide, $3^{\text {rd }}$ Edition, ISA.

[19] Mukhsen, A.F., Belyayev, M.A. and Filimonov, V.I. (1995), Electrical Technology (Russia), 2, 61.

[20] Astrom, K.J. and Hagglund, T. (1996). The Control Handbook, Ed.: W.S. Levine, CRC/IEEE Press, 198.

[21] Palmor, Z.J. (1996). The Control Handbook, Ed.: W.S. Levine, CRC/IEEE Press, 224.

[22] Kristiansson, B. and Lennartson, B. (1999). Proc. IFAC 1999 $14^{\text {th }}$ Word Congress, Preprints Vol. F, Lecture 2d-07-01.

[23] Astrom, K.J. and Hagglund, T. (2000). Preprints Proc. PID '00: IFAC Workshop on digital control, Terrassa, Spain, 19.

[24] Kleinmann, D.L. (1969). IEEE Transactions on Automatic Control, October, 524.

[25] Kantor, J.C. and Andres, R.P. (1980). International Journal of Control, 31, 655

[26] Donoghue, J.F. (1977). IEEE Transactions on Industrial Electronics and Control Instrumentation, IECI-24, 109.

[27] Cook, G. and Price, M.G (1978). IEEE Transactions on Industrial Electronics and Control Instrumentation, IECF 25, 180.

[28] Palmor, Z.J. and Shinnar, R. (1979). Industrial Engineering Chemistry Process Design and Development, 18(1), 8.

[29] Grimble, M.J. (1979). Proc. Institution of Electrical Engineers Control and Science, 126, 697.

[30] Hammerstrom, L.G. and Waller, K.V. (1980). IEEE Transactions on Industrial Electronics and Control Instrumentation, IECI-27, 301.

[31] Watanabe, K. and Ito, M. (1981), IEEE Transactions on Automatic Control, AC-26, 1261.

[32] Normey-Rico, J.E. and Camacho, E.F. (1999). IEEE Transactions on Automatic Control, 44(8), 1597.

[33] Harris, T.J., MacGregor, J.F. and Wright, J.D. (1982). The Canadian Journal of Chemical Engineering, 60, 425.

[34] Palmor, Z.J. (1982). Automatica, 18, 107.

[35] Clark, D.W. (1985). Self-tuning and adaptive control: theory and applications, IEE Control Engineering Series 15, Peter Peregrinus Ltd.

[36] Durbin, L.D. (1985). Proc. American Control Conference, 3, 1707.

[37] Astrom, K.J. and Wittenmark, B. (1984). Computer controlled systems: theory and design, Prentice-Hall International Inc.

[38] Morari, M. and Zafiriou, E. (1989). Robust process control, Prentice-Hall Inc.

[39] Blevins, T.L. (1979). Proc. ISA Conference and Exhibition, Chicago, IL., U.S.A., 34(2), 121

[40] Middleton, R.H. and Goodwin, G.C. (1990). Digital control and estimation: a unified approach, Prentice-Hall Inc.

[41] Soeterboek, R. (1992). Predictive control - a unified approach, Prentice-Hall Inc.

[42] Landau, I.D. (1995). International Journal of Control,62, 325.

[43] Grimble, M.J. (1998). IEE Proceedings - Control Theory and Applications, 145(5), 449

[44] Qin, S.J. (1998). Computers and Chemical Engineering, 23, 173.

[45] Zhang, W.-D., Sun, Y.-X. and Xu, X.-M. (1998). IEE Proceedings - Control Theory and Applications, 145, 159.

[46] Schneider, D.M. (1988). IEEE Transactions on Industry Applications, 24, 186.

[47] Singh, A. and McEwan, D.H. (1976). IEEE Transactions on Industrial Electronics and Control Instrumentation, IECF 22, 396.
[48] Parrish, J.R. and Brosilow, C.B. (1985). Automatica, 21, 527.

[49] Papageorgiou, M. and Messner, A. (1989). Automatica, 25, 177.

[50] Foss, B.A. and Wasbo, S.O. (1994). Automatica, 30, 593.

[51] Lin, F.J., Liaw, C.M., Shieh, Y.S., Guey, R.J. and Hwang, M.S. (1995). IEE Proceedings - Electrical Power Applications, 142(2), 79.

[52] Vrancic, D., Hanus, R. and Strmenik, S. (1998). Proc. IFAC Conference on System Structure and Control, Nantes, France, 2, 487.

[53] Hang, C.C., Lee, T.H. and Ho, W.K. (1993). Adaptive Control, Instrument Society of America.

[54] Tsang, K.M., Lo, W.L. and Rad, A.B. (1998). ISA Transactions, 37, 177

[55] Kaya, I. (2001). Industrial Engineering Chemistry Research, 40(12), 2654.

[56] Ingimundarson, A. (2001). Robust tuning procedures of deadtime compensation controllers, M.Sc. Thesis, Lund, Sweden.

[57] Hagglund, T. (1992). IEEE Control Systems Magazine, February, 57.

[58] Hansen, P.D. (1998), Proceedings of the American Control Conference, Philadelphia, Pennsylvania, U.S.A., 1, 131.

[59] Shinskey, F.G. (1994). Feedback controllers for the process industries, McGraw-Hill Inc.

[60] Shinskey, F.G. (2001). Control Engineering Practice, 9, 1177.

[61] Branica, I., Petrovic, I. and Peric, N. (1999). Progress Sim., Mod., Anal. Syn. Mod. Elect. Electron. Dev. Syst., N.E. Mastorakis (Ed.), 136.

[62] Shinskey, F.G. (1990). Measurement and Control,23, 114.

[63] Shinskey, F.G. (1990). Chemical Engineering, December, 96.

[64] Matausek, M.R. and Micic, A.D. (1996). IEEETransactions on Automatic Control, 41, 1199.

[65] Matausek, M.R. and Micic, A.D. (1999). IEEETransactions on Automatic Control, 44(8), 1603.

[66] Stojic, M.R., Matijevic, M.S. and Draganovic, L.S. (2001). IEEE Transactions on Automatic Control, 46(8), 1293.

[67] Normey-Rico, J.E., Bordons, C. and Camacho, E.F. (1997). Control Engineering Practice, 5, 801.

[68] Hashimoto, T. and Ishida, Y. (2000). ISA Transactions, 39(1), 71.

[69] Rad, A.B., Tsang, K.M. and Lo, W.L. (1995). IEE Proceedings - Control Theory and Applications, 142, 433.

[70] Lo, W.L. and Rad, A.B. (1995). International Journal of Modelling and Simulation, 15(3), 98.

[71] Hagglund, T. (1996). Control Engineering Practice, 4, 749.

[72] Ingimundarson, A. and Hagglund, T. (2000). Preprints Proc. PID '00: IFAC Workshop on digital control, Terrassa, Spain, 19

[73] Kravaris, C. and Wright, R.A. (1989). AIChE Journal,35(9), 1535.

[74] Young, C., O'Malley, M. and De Paor, A.M. (1990). International Journal of Control, 42, 261.

[75] Al-Sunni, F. and Al-Nemer, T. (1997). International Journal of Systems Science, 28, 1251.

[76] Tan, Y. and De Keyser, R. (1994). Proc. Third IEEE Conference on Control Applications, Glasgow, U.K., 2, 1429.

[77] Rad, A.B., Lo, W.L. and Tsang, K.M. (2000). IEEE Transactions in Industrial Electronics, 47(6), 1350.

[78] Xu, J.-X., Hu, Q., Lee, T.H. and Yamamoto, S. (2001). Journal of Process Control, 11, 321.

[79] Chiang, H.S. and Durbin, L.D. (1980). Proc. ISA Conference and Exhibition, Houston, Texas, U.S.A., 35(1), 57.

[80] Marshall, J.E. (1979). Control of time-delay systems, IEE Control Engineering Series 10. Peter Peregrinus Ltd.

[81] Bahill, A.T. (1983). IEEE Control Systems Magazine, 3(2), 16.

[82] Kaya, A. and Scheib, T.J. (1984). Proc. ISA International Conference and Exhibition, Houston, Texas, U.S.A., 843. 
[83] Malik-Zafarei, M. and Jamshidi, M. (1987). Time delay systems - analysis, optimisation and applications, Elsevier Science Publishers B.V.

[84] Liu, G. (1990). Advances in Modelling and Simulation, 20,9.

[85] Hang, C.-C., Wang, Q.-G. and Cao, L.-S. (1994). Proc. Asian Control Conference, Tokyo, Japan, 327.

[86] Hang, C.-C., Wang, Q.-G. and Cao, L.-S. (1995). International Journal of Adaptive Control and Signal Processing, 9, 255.

[87] Jones, A.H. and De Moura Oliveira, P.B. (1996). Proc. UKACC International Conference on Control, 454.

[88] O'Dwyer, A. (1996). The estimation and compensation of processes with time delays, Ph.D. thesis, Dublin City University, Dublin 9.

[89] Balestrino, A., Verona, F.B. and Landi, A. (1998). IEE Proceedings - Control Theory and Applications, 145, 231.

[90] Tian, Y.-C. and Gao, F. (1998). Industrial Engineering Chemistry Research, 37, 982.

[91] Palmor, Z.J. (1980). International Journal of Control,32, 937.

[92] Garcia, C.E. and Morari, M. (1985). Industrial and Engineering Chemistry Process Design and Development, 24, 472 .

[93] Laughlin, D.L., Rivera, D.E. and Morari, M. (1987). International Journal of Control, 46, 477.

[94] Yamanaka, K. and Shimemura, E. (1987). Automatica, 23, 787.

[95] Gorecki, H., Fuska, S., Grabowski, P. and Korytowski, A. (1989). Analysis and synthesis of time delay systems, John Wiley and Sons.

[96] Fisher, D.G. (1991). The Canadian Journal of Chemical Engineering, 69, 5.

[97] Santacesaria, C. and Scattolini, R. (1993). Automatica, 29, 1595.

[98] Wang, Z.-Q. and Skogestad, S. (1993). International Journal of Control, 57, 1405 .

[99] Shu, Z., Watanabe, K. and Yamade, K. (1994). Proc. Asian Control Conference, Tokyo, Japan, 1045.

[100] Wang, Z.-Q., Lundstrom, P. and Skogestad, S. (1994). International Journal of Control, 59, 627.

[101] Lee, T.H., Wang, Q.G. and Tan, K.K. (1996). AIChE Journal, 42, 1033 .

[102] De Moura Oliveira, P.B. and Jones, A.H. (1997). Proc. $2^{\text {nd }}$ Int. Conf. Eng. Syst. (GALESIA '97), Glasgow, Scotland, 504.

[103] De Moura Oliveira, P.B. and Jones, A.H. (2000). Preprints Proc. PID '00: IFAC Workshop on digital control, Terrassa, Spain, 205

[104] Lee, D., Lee, M., Sung, S. and Lee, I. (1999). Journal of Process Control, 9, 79.

[105] Carr, S. and O’Dwyer, A. (1999). Proc. Irish Signals and Systems Conference, Galway, 45.

[106] Sun, D. and Hoo, K.A. (1999). International Journal of Control, 72(2), 150.

[107] Adam, E.J., Latchman, H.A. and Crisalle, O.D. (2000). Proc. American Control Conference, Chicago, Illinois, U.S.A., 1452.

[108] Vandeursen, J.M. and Peperstraete, J.A. (1995). International Journal of Control, 62, 983.

[109] Semino, D. and Brambilla, A. (1996). Industrial Engineering Chemistry Research, 35, 1845.

[110] Liu, K., Shimizu, T., Inagaki, M. and Ohkawa, A. (1998) Journal of Chemical Engineering of Japan, 31(3), 320-324.

[111] Ioannides, A.C., Rodgers, G.J. and Latham, V. (1979). International Journal of Control, 29, 557.

[112] Vit, K. (1979). International Journal of Control,31, 179.

[113] Marshall, J.E. and Salehi, S.V. (1982). IEE Proceedings, Part D, 129, 177

[114] Hocken, R.D., Salehi, S.V. and Marshall, J.E. (1983) International Journal of Control, 38, 433.

[115] Chotai, A., Owens, D.H., Raya, A. and Wang, H.M. (1984) International Journal of Control, 40(2), 297.

[116] Tan, K.K., Wang, Q.G., Lee, T.H. and Bi, Q. (1996). AIChE Journal, 42, 1793.
[117] Tan, K.K., Lee, T.H. and Ferdous, R. (1999). Industrial Engineering Chemistry Research, 38(9), 3438.

[118] Wang, Q.-G., Bi, Q. and Zhang, Y. (2000). ISA Transactions, 39(1), 79

[119] Sung, S.W. and Lee, I.-B. (1996). Industrial Engineering Chemistry Research, 35, 2596.

[120] Hang, C.C. and Wong, F.S., (1979). Proc. ISA Conference and Exhibition, Chicago, IL., U.S.A., 34(2), 33.

[121] Chiang, H.S. and Durbin, L.D. (1981). Proc. ISA Conference and Exhibition, Anaheim, CA., U.S.A., 36(2), 17.

[122] Durbin, L.D. (1981). Proc. ISA Conference and Exhibition, Anaheim, CA., U.S.A., 36(2), 315

[123] Watanabe, K., Ishiyama, Y. and Ito, M. (1983). International Journal of Control, 73, 959.

[124] Palmor, Z.J. and Powers, D.V. (1985). AIChE Journal,31, 215.

[125] Wong, S.K.P. and Seborg, D.E. (1986). AIChE Journal,32, 1597.

[126] Romagnoli, J.A., Karim, M.N., Agamennoni, O.E. and Desages, A. (1988). IEE Proceedings, Part D, 135, 157.

[127] Huang, H.-P., Chen, C.-L., Chao, Y.-C. and Chen, P.-L. (1990). AIChE Journal, 36, 1025.

[128] Mitchell, R.J. (1990). Transactions of the Institute of Measurement and Control, 12, 58

[129] Deshpande, P.B. (1991). Chemical Engineering Progress, May, 71.

[130] Deshpande, P.B., Hannuala, R.E., Bhalodia, M.A. and Hansen, C.W. (1993). Chemical Engineering Progress, July, 59.

[131] Astrom, K.J., Hang, C.C. and Lim, B.C. (1994). IEEE Transactions on Automatic Control, 39, 343.

[132] Zhang, W.D. and Sun, Y.X. (1996). Industrial Engineering Chemistry Research, 35, 2769.

[133] Zhang, W.-D., Sun, Y.-X. and Xu, X.-M. (1998) Automatica, 34(10), 1279

[134] Leonard, F. (1998). Proc. IFAC Conference: System Structure and Control, Nantes, France, 571.

[135] Vrancic, D., Badillo, S.O.A. and Strmcnik, S. (1998). Proc. $7^{\text {th }}$ Electrotech. Comp.Sci. Conf., Portoroz, Slovenia, A, 287

[136] Vrancic, D., Vrecko, D., Juricic, D. and Strmcnik, S. (1999). Proc. American Control Conference, Preprints, Session FM14.

[137] Benouarets, M. and Atherton, D.P. (1994). Proc. IEE International Conference on Control, 795.

[138] Ferriera, A.M.P. (1994). Proc. $3^{\text {rd }}$ IEEE Conference on Control Applications, 3, 1777.

[139] Dastych, J. (1995). EURACO Workshop: Recent results in robust and adaptive control, Florence, Italy, 420.

[140] Ebach, U. and Graser, A. (1995). Control Engineering Practice, 3, 1467.

[141] Gorecki, R. and Jekielek, J. (1997). Proc. ISA Tech/Expo Technology Update, Anaheim, California, 1(5), 113

[142] Gorecki, R. and Jekielek, J. (1999). ISA Transactions, 38, 37.

[143] Copp, D.G., Burnham, K.J. and Lockett, F.P. (1998). Proc. UKACC International Conference on Control, Swansea, Wales, 1, 670

[144] Smith, L. (1999). IEE Computing and Control Engineering Journal, April, 57.

[145] Tian, Y.-C. and Gao, F. (1998). Transactions of the Institute of Chemical Engineers, 76(A), 445.

[146] Tian, Y.-C. and Gao, F. (1998). IEE Proceedings - Control Theory and Applications, 145(5), 479.

[147] Tian, Y.-C. and Gao, F. (1999). Industrial Engineering Chemistry Research, 38(9), 3396.

[148] Tian, Y.-C. and Gao, F. (1999). Industrial Engineering Chemistry Research, 38(8), 2979.

[149] Debelak, K.A. and Rutherford, M.L. (1999). Industrial Engineering Chemistry Research, 38(10), 4113.

[150] Majhi, S. and Atherton, D.P. (1999). IEE Proceedings Control Theory and Applications, 146(5), 359.

[151] Kwak, H.J., Sung, S.W. and Lee, I-B. (2001). Industrial Engineering Chemistry Research, 40(6), 1500. 
[152] Palmor, Z.J. and Halevi, Y. (1990). Automatica, 26, 637.

[153] Whalley, R. and Zeng, Z. (1994). Transactions of the Institute of Measurement and Control, 16, 174.

[154] Chien, I.-L., Seborg, D.E. and Mellichamp, D.A. (1985). International Journal of Control, 42, 949.

[155] Hang, C.C., Lee, T.H. and Tay, T.T. (1985). Proc. ISA/85 International Conference and Exhibition, Philadelphia, U.S.A., 40(1), 387.

[156] Batur, C. (1986). Proc. American Control Conference, Seattle, Washington, U.S.A., 2, 1354

[157] Wang, F.-S. (1990). Optimal Control Applications and Methods, 11, 211.

[158] Fujikawa, H. and Yamada, S.-I. (1991). Proc. International Conference on Industrial Electronics - IECON'91,3,1801.

[159] Guez, A. and Piovoso, M. (1991), Proc. American Control Conference, 2, 1592

[160] Mills, P.M., Lee, P.E. and McIntosh, P. (1991). Automatica, 27, 441 .

[161] Behbehani, K., Delpasse, J.S. and Klein, K.W. (1993). International Journal of Control, 58, 1215.

[162] Batur, C. (1985). Proc. ISA/85 International Conference and Exhibition, Philadelphia, Penn., U.S.A., 40(1), 637.

[163] Teng, F.-C. (1990). Transactions of the Institute of Measurement and Control, 12, 224.

[164] Chen, C. -L. and Jong, M.-J. (1993). Proc. Second IEEE International Conference on Fuzzy Systems, San Francisco, U.S.A., 236.

[165] Chotai, A. and Young, P.C. (1985). Proc. IEE Control Conference, 218.

[166] Chotai, A. and Young, P.C. (1987). Proc. IEE Colloquium on Control of Time Delay Systems, London, U.K., Digest 1987/115, 2/1.

[167] Taylor, J., Chotai, A. and Young, P. (1998). Proc. Institute of Mechanical Engineers, 212, 37.

[168] Lees, M.J., Taylor, C.J., Young, P.C. and Chotai, A. (1998). Control Engineering Practice, 6, 1209.

[169] Daniel, P. and Cox, C.S. (1995). International Journal of Systems Science, 26(1), 113.

[170] Cox, C.S. and Adgar, A. (2000). An introduction to PIP control, Technical Report, Control Systems Centre, University of Sunderland.

[171] Walgama, K.S., Fisher, D.G. and Shah, S.L. (1989). AIChE Journal, 35, 213 .

[172] Hang, C.C., Lim, K.W. and Chong, B.W. (1989). Automatica, 25, 1.

[173] Roffel, B. and Chin, P.A. (1987). Hydrocarbon Processing, December, 40

[174] Zhu, J.J-M. and Saucier, M. (1992). Proc. American Control Conference, Chicago, Il., U.S.A., 1, 601.

[175] De La Cruz, J.M., Dormido, S. and Velasco, F. (1993). Proc. Conference on Systems, Man and Cybernetics, 63.

[176] Li, J., Yuan, D.C. and Jiang, C.H. (1994). Proc. Asian Control Conference, Tokyo, Japan, 209.

[177] Whalley, R. and Zeng, Z. (1996). Transactions of the Institute of Chemical Engineers, 74(A), 21.

[178] Mulholland, M. and Fernandes, L.A.R. (1997). Computers and Chemical Engineering, 21, 1283.

[179] Yamamoto, T., Oki, T. and Kanada, M. (1997). Electrical Engineering in Japan, 118(3), 50.

[180] Moore, C.F., Smith, C.L. and Murrill, P.W. (1969). Instrument Practice, January, 45

[181] Deshpande, P.B., Gopalratnam, P.C. and Ash, R.H. (1979), Proc. ISA Conference and Exhibition, Chicago, IL., U.S.A., 34(2), 131

[182] Deshpande, P.B. and Ash, R.H. (1983). Elements of computer process control with advanced control applications, Prentice-Hall Inc.

[183] Huang, H.-P. and You, H.-S. (1994). International Journal of System Science, 25, 991.

[184] Wellons, M.C. and Edgar, T.F. (1987). Industrial Engineering Chemistry Research, 26, 1523.

[185] Peter, K. and Isermann, R. (1988). Proc. IFAC Adaptive Control of Chemical Processes Conference, Copenhagen, Denmark, 69.
[186] Hammami, M., Turgeon, A.-B. and Bensoussan, D. (1992). Proc. 31st Conf. Decision Control, Tucson, Arizona, U.S.A., 183.

[187] Zafiriou, E. and Morari, M. (1985). International Journal of Control, 42, 865 .

[188] Shahrohki, M. and Naimpour, F. (1992). Computers and Chemical Engineering, 16, 1073.

[189] Peebles, S.M., Hunter, S.R. and Corripio, A.N. (1994) Computers and Chemical Engineering, 18, 995.

[190] Vandeursen, J.M. and Peperstraete, J.A. (1996). ISA Transactions, 35, 225.

[191] Jones, A.H. and Lin, Y.-C. (1998). Proc. UKACC International Conference on Control, Swansea, Wales, 2 , 1599.

[192] Normey-Rico, J.E., Gomez-Ortega, J. and Camacho, E.F. (1999), Control Engineering Practice, 7, 729.

[193] Normey-Rico, J.E. and Camacho, E.F. (1999), IEE Proceedings - Control Theory and Applications, 146(2), 179.

[194] Normey-Rico, J.E. and Camacho, E.F. (2000), IEE Proceedings - Control Theory and Applications, 147(5), 538.

[195] Alevisakis, G. and Seborg, D.E. (1974). Chemical Engineering Science, 29, 373.

[196] Ogunnaike, B.A. and Ray, W.H. (1979). AIChE Journal, 25, 1043.

[197] Ray, W.H., Advanced process control. McGraw-Hill, 1981.

[198] Watanabe, K. and Sato, M. (1984). International Journal of Control, 39, 1.

[199] Chien, I.-L., Mellichamp, D.A. and Seborg, D.E. (1985). Proc. IFAC Ident. System Parameter Estimation Conference, York, U.K., 1261.

[200] Bhaya, A. and Desoer, C.A. (1985). International Journal of Control, 41(3), 813

[201] Jerome, N.F. and Ray, W.H. (1986). AIChE Journal,32, 914.

[202] Ozturk, N. and Fardanesh, B. (1991). Proc. Int. Conf. Ind. Electronics, Control and Instrumentation (IECON'91), Kobe, Japan, 2, 1191.

[203] Triantafyllou, M.S. and Grosenbaugh, M.A. (1991). IEEE Journal on Oceanic Engineering, 16, 146.

[204] Austin, P.C., Crawford, R.A. and Carter, M.R. (1993). Proc. IFAC 12th World Congress, Sydney, Australia, 2, 223.

[205] Desbiens, A., Pomerleau, A. and Hodouin, D. (1996). IEE Proceedings - Control Theory and Applications, 143, 49.

[206] Pandiscio, A.A. and Pearson, A.E. (1993). Proc. American Control Conference, San Francisco, California, U.S.A., 499.

[207] Stankovski, M.J., Dimirovski, G.M., Gough, N.E. and Hanus, R. (1998). Proc. UKACC Int. Conf. Control, Swansea, Wales, 1, 946.

[208] Vlachos, C., Williams, D. and Gomm, J.B. (1998). Proc. UKACC International Conference on Control, Swansea, Wales, 2, 1587.

[209] Doering, J.A. and Parker, G.G. (2000). Proc. American Control Conference, Chicago, Illinois, U.S.A., 2501.

[210] Wang, Q.-G., Zou, B. and Zhang, Y. (2000). Transactions of the Institute of Chemical Engineers, 78(A), 565.

[211] Owens, D.H. and Raya, A. (1982). IEE Proceedings, Part D, 129, 298.

[212] Palmor, Z.J. and Halevi, Y. (1983). Automatica, 19, 255.

[213] Chu, Y.T. and Wu, W.-T. (1986). IEEE Transactions on Automatic Control, AC-31, 157

[214] Feng, W. (1991). Automatica, 27, 389.

[215] Shin, S.S. and Park, S.W. (1990). Korean Journal of Chemical Engineering, 7(2), 115

[216] Luo, X., Sun, X. and Zhou, C. (1992). Industrial and Engineering Chemistry Research, 31, 1418.

[217] Wu, W.-T. and Tseng, C.-G. (1992). Transactions of the Institute of Measurement and Control, 14, 204.

[218] Wu, W.-T., Tseng, C.-G. and Chu, Y.T. (1994). International Journal of System Science, 25, 423.

[219] Maciejowski, J.M. (1994). Journal of Process Control,4, 29. 
[220] Mhatre, S. and Brosilow, C. (2000). AIChE Journal, 46(8), 1566.

[221] Furukawa, T. and Shimemura, E. (1983). International Journal of Control, 37, 399.

[222] De Paor, A.M. (1985). International Journal of Control, 41, 1025.

[223] De Paor, A.M. and Egan, R.P.K. (1990). International Journal of Control, 51, 341

[224] Kwak, H.J., Sung, S.W. and Lee, I.-B. (1999). Industrial Engineering Chemistry Research, 38(2), 404.

[225] Niculescu, S.-I. and Annaswamy, A.M. (2000). Proc. American Control Conference, Chicago, Illinois, USA, 3666.

[226] O'Dwyer, A. and Ringwood, J.V. (1995). Proc. Irish Colloquium on DSP and Control, Queens University, Belfast, 39. 